3 Elsa B. Girard ${ }^{\mathrm{a}, 1}$, Adrian Fuchs $^{\mathrm{b}}$, Melanie Kaliwoda ${ }^{\mathrm{c}}$, Markus Lasut ${ }^{\mathrm{d}}$, Evelyn Ploetz ${ }^{\mathrm{b}}$, Wolfgang

4 W. Schmahl ${ }^{\mathrm{a}, \mathrm{e}}$, Gert Wörheide ${ }^{\mathrm{a}, \mathrm{e}, \mathrm{f} *}$

5

6 a Department of Earth and Environmental Sciences, Ludwig-Maximilians-Universität

7 München, 80333 Munich, Germany

$8{ }^{b}$ Department of Chemistry and Center for Nanoscience (CeNS), Ludwig-Maximilians-

9 Universität München, 81377 Munich, Germany

$10{ }^{\mathrm{c}}$ Mineralogische Staatssammlung München (SNSB), 80333 München, Germany

$11{ }^{\mathrm{d}}$ Faculty of Fisheries and Marine Science, Sam Ratulangi University, Jalan Kampus Unsrat

12 Bahu, Manado 95115, Sulawesi Utara, Indonesia

13 e GeoBio-Center ${ }^{\mathrm{LMU}}$, Ludwig-Maximilians-Universität München, 80333 Munich, Germany

$14{ }^{\mathrm{f}}$ SNSB - Bayerische Staatssammlung für Paläontologie und Geologie, 80333 Munich,

\title{
15 Germany
}

*Corresponding author: Gert Wörheide - woerheide@lmu.de

Present address:

\footnotetext{
${ }^{1}$ Naturalis Biodiversity Center, 2300 RA Leiden, The Netherlands
} 


\section{$30 \quad$ ABSTRACT}

Amongst other threats, the world's oceans are faced with man-made pollution, including an increasing number of microparticulate pollutants. Sponges, aquatic filter-feeding animals, are able to incorporate fine foreign particles, and thus may be a potential bioindicator for microparticulate pollutants. To address this question, 15 coral reef demosponges sampled around Bangka Island (North Sulawesi, Indonesia) were analyzed for the nature of their foreign particle content using traditional histological methods, advanced light microscopy, and Raman spectroscopy. Sampled sponges accumulated and embedded the very fine sediment fraction $(<$ $200 \mu \mathrm{m}$ ), absent in the surrounding sand, in the ectosome (outer epithelia) and spongin fibers (skeletal elements), which was confirmed by two-photon microscopy. A total of 34 different particle types were identified, of which degraded man-made products, i.e., polystyrene, cotton, titanium dioxide and blue-pigmented particles, were incorporated by eight specimens at concentrations between 91 to 612 particle/g dry sponge tissue. As sponges can weigh several hundreds of grams, we conservatively extrapolate that sponges can incorporate on average 10,000 microparticulate pollutants in their tissue. The uptake of particles, however, appears independent of the material, which suggests that the fluctuation in material ratios is due to the spatial variation of surrounding microparticles. Therefore, sponges have a strong potential to biomonitor microparticulate pollutants, such as microplastics and other degraded industrial products. 
INTRODUCTION

Microparticulate pollutants (later referred to as "micropollutants") are a threat to inhabitants of the world's oceans. Here, we define micropollutants as man-made substances, or products of their subsequent degradation, smaller than $5 \mathrm{~mm}$ in size. They are introduced into the environment and are potentially harmful to organisms, for instance as microplastics, textile fibers and particulate toxins leach from household and cosmetic products (Dris et al. 2016; Auta et al. 2017; Rochman 2018). Because traditional sieving techniques fail to assess the very fine particulate fraction $(<200 \mu \mathrm{m})$ adequately (Lindeque et al. 2020), the main question driving this research is whether potential bioindicators for such anthropogenic micropollutants can be identified among marine organisms. widely spread (Bell 2008). They consume mainly dissolved organic carbon (DOC), prokaryotes and ultraphytoplankton $(<10 \mu \mathrm{m})$ by filtering fine particles from the ambient water (Yahel et al. 2006). They incorporate particles following two main paths: (1) phagocytosis by choanocytes and (2) endocytosis through the exopinacoderm (Willenz and van de Vyver 1982; Teragawa 1986a). First, choanocytes, i.e., cells that generate the water flow in the sponge body through the beating activity of their flagellum, filter the water and capture the nutritive particles via phagocytosis (Hammel and Nickel 2014). The ingested particles are thought to be directly transferred from choanocytes to archaeocytes, which might be responsible for the digestion and transportation of nutrients to different sites in the sponge body (Willenz and van de Vyver 1982). Second, exopinacocytes may incorporate particles as big as $2 \mathrm{~mm}$ diameter, which deposited on the outside of the animal on the ectosome (Cerrano et al. 2002). Such microparticles may subsequently be transported by ameboid mesohyl cells from the ectosome towards sites of skeletogenesis in non-spiculated demosponges (Teragawa 1986a). This 
process is also associated with the spicule transport within the mesohyl by collencytes in spiculated Demospongiae (Teragawa 1986a). Foreign microparticles provide sponges with strength and support their growth (Teragawa 1985). They may also serve for protection (Burns and Ilan 2003) and anchorage to the substrate (Cerrano et al. 2002); Teragawa 1986b). However, mechanisms behind particle incorporation, retention and rejection in sponges are not fully understood yet. Nonetheless, we hypothesize that the fluctuation in material ratios incorporated by sponges is due to the spatial variation of surrounding microparticles; therefore, sponges may incorporate man-made micropollutants if present in their immediate environment and be viable models for biomonitoring such.

To address this issue, we carried out a combination of field and laboratory studies. The sampling of sponges was conducted in Indonesia since it is known to be a hotspot for landbased pollution in the middle of the Coral Triangle (Eriksen et al. 2014). Collected sponges were then transported to the home laboratories to locate, identify and quantify foreign particles, including micropollutants, within sponge bodies. We used histological methods, such as (nonlinear) light microscopy, as well as Raman spectroscopy for five poriferan species from Bangka Island (North Sulawesi, Indonesia) to address the following three questions: in which structure(s) do particles accumulate?; what kind of particles do sponges incorporate (diversity)?; do sponges have the potential to monitor microparticulate pollutants? Findings

97 from this study contribute to fill a knowledge gap on particle incorporation by sponges. Indeed, sampled sponges appeared to be efficient sediment traps as they accumulated the very fine sediment fraction $(<200 \mu \mathrm{m})$, absent in the surrounding sand, in the ectosome and spongin fibers. A total of 34 different particle types were identified, of which degraded man-made products, such as polystyrene, cotton, titanium oxides and blue-pigmented particles, were incorporated by eight specimens. The incorporation of particles, however, appears independent of the material, which suggests that the fluctuation in material ratios is due to the spatial 
variation of surrounding microparticles. Therefore, sponges have a strong potential to products.

MATERIAL AND METHODS

Site of study and sample collection.

The field work took place at Coral Eye Resort on the west coast of Bangka Island

113 (Kabupaten Minahasa Utara, Perairan Likupang), Sulawesi Utara, between March 17th and

114 April 12th 2019, to assess the plastic contamination in marine sponges (research permit holder:

115 Elsa Girard; SIP no.: 97/E5/E5.4/SIP/2019). The sampling area spanned approximately $7 \mathrm{~km}^{2}$

116 and specimens were sampled at three different locations: Coral Eye house reef, South and North

117 of the jetty, and the mangroves (Supplementary material Fig. S1, Tab. S1). Non-lethal samples

$118(\mathrm{n}=101)$ were taken on a wide variety of marine sponge species and sizes, using a stainless-

119 steel diving knife, while snorkeling (free-diving). All sponges were sampled between 1 and 5

120 m water depth. Samples were collected in Kautex ${ }^{\mathrm{TM}}$ PVC wide neck square containers (250

121 and $500 \mathrm{~mL}$ ) filled with ambient seawater until further treatment at Coral Eye Resort

122 laboratory. An in situ picture of each specimen was taken, showing the macro-morphological

123 features of the species. In addition, one sand sample from Coral Eye Resort was collected for 124 comparison in the intertidal zone near the jetty (later referred to as beach sand).

Specimen selection.

A superficial inspection of the collected samples was done at Coral Eye Resort

128 laboratory in order to assess the presence of foreign particles in the sponge tissue, potentially 
containing microplastics. Two techniques were used. In a first step, the samples were enzymatically digested with $0.2 \mathrm{~mL}$ Proteinase-K $(20 \mathrm{mg} / \mathrm{mL})$ mixed to $2 \mathrm{~mL}$ Tris-HCl buffer

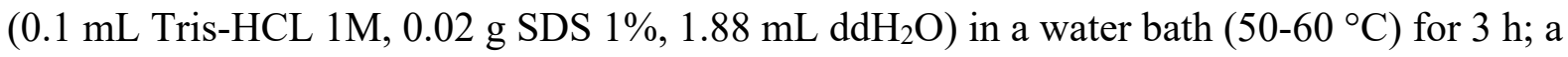

132 drop of the resulting solution was transferred on a microscope slide for inspection. In a second 133 step, each sample was scrutinized with binoculars to search for apparent foreign particles within the sponge tissue. Specimens were selected depending on their foreign particle content for further downstream analysis, i.e., molecular species identification, histological and Raman spectroscopy analyses. Once a specimen-type was selected, two other specimens of apparently the same species were also sampled to create triplicates, i.e., 3 specimens of the same species. A total of 15 specimens were sampled, i.e., from five different species, for further downstream analysis. Collected samples were preserved in two aliquots: $96 \%$ ethanol for DNA barcoding and $4 \%$ formaldehyde for histology and spectroscopy.

\section{Species identification.}

At the Molecular Geobiology and Paleobiology laboratory of the Department of Earth

144 \& Environmental Sciences, Paleontology \& Geobiology, LMU Munich, specimens were 145 identified to the genus using an integrative approach (Wörheide and Erpenbeck 2007; Voigt and Wörheide 2016). The DNA was extracted from the samples using a DNA extraction kit

147 (NucleoSpin ${ }^{\circledR}$ Tissue, Macherey-Nagel GmbH \& Co. KG). DNA barcoding was conducted 148 using a fragment of the 28S ribosomal DNA, a region amplified using universal primers via 149 polymerase chain reaction (PCR) (Supplementary material Tab. S2). PCR products were run through an agarose gel $(1 \%)$ to verify that the amplification was correctly performed and amplified fragments were of expected length (ca. $550 \mathrm{bp}$ ). The DNA was sequenced with

152 BigDyeTerminator v3.1. Sanger Sequencing was conducted at the Genomic Sequencing Unit 153 of the LMU Munich, using an ABI 3730 (Erpenbeck et al. 2017). 

were combined to the $28 \mathrm{~S}$ sponge data set (Erpenbeck et al. 2016) available at the Sponge

158 Genetree Server (www.spongegenetrees.org). The data set was largely reduced to concentrate on the important clades, by selecting only the nearby taxa (taxonomically classified) with the least genetic distance to the samples. Alignments were performed in MAFFT v7.427

161 (https://mafft.cbrc.jp/alignment/software/), default settings. Subsequently, phylogenetic trees 162 were calculated for $28 \mathrm{~S}$ sequences in Seaview v4.6.3 (Gouy et al. 2010) under PhyML

$163 \mathrm{GTR}+\mathrm{G}+\mathrm{I}$ model with the invariable site and gamma shape settings obtained via jmodeltest 1642.1 .10 v20160303 (Darriba et al. 2012), and included 100 bootstrap replicates (Guindon et al. 2010). FigTree v1.4.3 (http://tree.bio.ed.ac.uk/) and Adobe Illustrator CS3 were employed to modify the esthetic of the figures. Final barcoding data (alignments and trees) is stored on

GitHub repository (https://github.com/PalMuc/PlasticsSponge).

\section{Histological analysis.}

The samples were fixed with $4 \%$ formaldehyde and gradually dehydrated with ethanol at the Coral Eye Resort laboratory (Indonesia). At the molecular laboratory in Munich, samples were prepared for thin sectioning in LR-white medium to preserve the original position of

173 foreign particles within the tissue. Sections with a thickness ranging between 50 to $400 \mu \mathrm{m}$ 174 were cut depending on the specimen morphology, using a saw microtome (Leica SP1600). Two freshly cut sections per sample (30 to $50 \mu \mathrm{m}$ thick) were stained using Carbol Fuchsin dye (Roth staining kit) to highlight the cellular distribution within the mesohyl, including

177 choanocyte chambers. Sections were mounted on microscope slides using Eukitt Quick-

178 hardening mounting medium. The histological analysis was conducted using a microscope 
179 Leica DMLB (Type 020-519.502 LB30 T BZ:00, Leica Mikroskopie \& Systeme GmbH

180 Wetzlar) with a mounted digital camera. Images of the same field of views were taken under

181 brightfield and (cross-)polarized light illumination. The polarized light fields allowed a better

182 recognition of the foreign particles in the sponge, embedded in the organic tissue. Field of

183 views of the ectosome, mesohyl, skeletal structures and aquiferous system (i.e., canals and choanocyte chambers) were recorded for each specimen. The histological analysis also enabled the description of the sponge main morphological micro-features.

In addition to the assessment of particle accumulation areas, relative particle abundance and size were analyzed with ImageJ v1.52K (Schindelin et al. 2012). All tissue images utilized for the analysis were taken under the same settings $(100 \mu \mathrm{m}$ thin section, equal luminosity and magnification) to ensure comparability of the data. To measure the particle's relative abundance, images were translated into grayscale (8-bit) and the mean light intensity of ten random square areas $(264.52 \mu \mathrm{m}$ side length) were measured per structure and per sample. The mean light intensity is a numerical value generated by the software that allows for a comparison between areas and samples with an arbitrary unit (AU). Unpolarized light illumination was chosen for keratose sponges, because the spongin tissue from the skeletal fibers has a high transmission with little scattering comparable to the particles. On the contrary, (cross)polarized light illumination was used for heteroscleromorphs, to observe particles in these heavily spiculated specimens with high organic matter content. Images taken with polarized light were treated in a second step by inverting the gray scale in order to have dark particles on a pale

199 background, similarly to the images taken with unpolarized light. Therefore, the lower the intensity value, the darker the area and the more particles are present. The particle size was also assessed and categorized with Image J: small (most particles $<50 \mu \mathrm{m}$ diameter), large (most particles $>50 \mu \mathrm{m}$ diameter) or mix (presence of small and large particles at a similar fraction).

203 The data gathered from the particle distribution, abundance and size was analyzed in R v3.3.3 
204 (R Core Team 2017). Primary data and R scripts are available on GitHub repository (https://github.com/PalMuc/PlasticsSponge).

\section{Particle distribution with two-photon excitation.}

Histological sections of sponge tissue were analyzed by two-photon excitation (TPE)

3D imaging, to highlight the contrast between the highly fluorescent organic tissue from the

211 Samples were evaluated after histological preparation. For two-photon imaging, fresh sections

212 of $170 \mu \mathrm{m}$ thickness were prepared without staining and mounted on microscope slides using

213 Eukitt Quick-hardening mounting medium. Brightfield pictures of the scanned area were taken

214 before the experiment followed by a 3D scan of the specimen. Each 2D image had a range of

$215190 \mu \mathrm{m}$, an acquisition time of $180 \mathrm{~s}$ and a step size of $380 \mathrm{~nm}$. The 3D step size between the

$2162 \mathrm{D}$ image planes and the total number of planes was chosen with respect to the object of interest

217 and ranged from 10 to 21 planes with 0.5 to $3 \mu \mathrm{m}$ steps.

Imaging was carried out on a confocal scanning microscope (TE 300; Nikon) with mounted bright-field illumination and camera. The two-photon excitation source was a fiberbased, frequency-double erbium laser (FemtoFiber dichro bioMP, Toptica Photonics) running at $774 \mathrm{~nm}$. The laser power was $10 \mathrm{~mW}$. The laser light was coupled into the microscope via a low pass dichroic mirror (HC BS 749 SP; AHF Analysetechnik) that separates laser excitation and fluorescence emission. Scanning of the sample in 3D was achieved by using a xyz piezo stage (BIO3.200; PiezoConcept). The laser excitation was focused onto the sample with a 60x (water) 1.20-NA plan apochromat objective (Plan APO VC 60x 1.2 NA, Nikon). The emission was collected by the same objective and passed afterwards through a bandpass filter (SP600; AHF). The emission was recorded on an APD detector (Count Blue; Laser Components) and its photons stream registered using a TCSPC card (TH260 pico dual; PicoQuant GmbH). The 
experiment was controlled using a home-written program written in C\#. The confocal data was extracted and evaluated afterwards by PAM (Schrimpf et al. 2018) and ImageJ2 (Schindelin et al. 2012).

\section{Raman spectroscopy.}

Raman spectroscopy method permitted the identification and quantification of particles on a filter and in situ, i.e., from thin sections. As preparation for Raman measurements, samples were firstly subsampled, dried and weighed. The subsamples weighed between 2.2 and $11 \mathrm{mg}$. The sponge tissue was digested in $1.5 \mathrm{~mL}$ household bleach over 2-3 days, with a one-time bleach renewal. Subsamples were then washed with MilliQ water five times in a row. Particles left were filtered through a nitrocellulose membrane (Whatman ${ }^{\mathrm{TM}}, 1 \mu \mathrm{m}$ mesh size) with the aid of a vacuum pump. One hundred particles were randomly measured per sample (referred to as "random" search pattern). Furthermore, a maximum of ten additional particles per sample were measured by purpose depending on differences in color, shape and texture to assess the diversity of incorporated particles in lower abundance (referred to as "target" search pattern). The same method was performed on the beach sand sample. In addition, the spectrum of white and a red sclerites of Tubipora musica (sample number GW1858, obtained from an individual grown in aquarium at the Molecular Geobiology and Paleobiology laboratory) was measured to compare its red pigment signal to that of the red particles present in sponges. Moreover, one thin section (30-50 $\mu \mathrm{m}$ thick) per triplicate was chosen to confirm the presence of in situ particles, which are not organic matter. Five to six particles were measured in each structure for all five sections.

Raman spectra were taken on a confocal Raman microscope (HORIBA JOBIN YVON XploRa ONE micro Raman spectrometer) belonging to the Mineralogical State Collection Munich (SNSB). The used Raman spectrometer is equipped with a Raman edge longpass filter, 
254 a Peltier cooled CCD detector and three different lasers working at $532 \mathrm{~nm}$ (green), $638 \mathrm{~nm}$

255 (red) and $785 \mathrm{~nm}$ (near IR). Here, $532 \mathrm{~nm}$ excitation was used to perform the measurements, 256 with a long working distance (LWD) objective magnification 100x (Olympus, series 257 LMPlanFL N), resulting in a $0.9 \mu \mathrm{m}$ laser spot size on the sample surface. The set power 258 required for high-quality spectra varied between $10 \%$ and $100 \%$ (i.e., respectively $0.879 \mathrm{~mW}$ and $8.73 \mathrm{~mW}+/-0.1$ on the sample surface) depending on the type and size of measured particles. The diameter of pin-hole and the slit width were set to 300 and $100 \mu \mathrm{m}$, respectively. Each acquisition included two accumulations with an integration time of $8 \mathrm{~s}$ over a spectral range of 50 to $2000 \mathrm{~cm}^{-1}$ (ca. $35 \mathrm{~s}$ per measurement). Resulting Raman spectra were analyzed using LabSpec Spectroscopy Suite software v5.93.20, compiled in a table, visualized in R v3.3.3, manually sorted in Adobe Illustrator CS3, and compared with available spectra from RRUFF database (see: http://rruff.info/index.php) and published work (e.g., (Zięba-Palus and Michalska 2014). The statistical ANOSIM test (Analysis of Similarity) was performed in R v3.3.3, using 999 permutations in the vegan package (Oksanen et al. 2017) to assess the similarity in foreign particle assemblage composition between species, subclasses and sampling locations. Raman spectra and analysis scripts written in $\mathrm{R}$ used for the analysis are available on GitHub repository (https://github.com/PalMuc/PlasticsSponge).

\section{Precautions against contaminants.}

To avoid contamination of the samples, latex gloves, glassware, cotton towel and dust-

274 free wipers (Kimtech Science) were used when manipulating the samples at all times. All open manipulations done in Molecular Geobiology and Paleobiology laboratory at LMU, i.e., dissection and filtration of the samples, were conducted under a clean bench (BDK, Luft- und

277 Reinraumtechnik GmbH). Eppendorf safe-lock tubes $1.5 \mathrm{~mL}$ (polypropylene) were used to centrifuge the subsamples during tissue digestion and subsequent washing steps. Consequently, 
a negative sample was included, undergoing the same steps as all sponge samples from tissue

281 Eye Resort laboratory and the presence of fibers on the negative filter, all resulting fibers in

282 this study were regarded as contaminants and therefore not taken into account. Only

283 microparticles, excluding microfibers, were analyzed.

\section{RESULTS}

Fourteen out of 82 morphologically different specimens (17\%) contained foreign particles based on the superficial analysis conducted at Coral Eye Resort laboratory. Five particle-bearing species were particularly abundant on site (Bangka Island, Indonesia), and sampled three times to generate the triplicates $(n=15)$. In order to determine the accumulation areas of foreign particles in coral reef sponges, the 15 samples were taxonomically classified to the genus level into 5 clades: Carteriospongia, Ircinia I, Ircinia II, Tethyid I and Tethyid II

293 (Supplementary material Fig. S2, Tab. S3) and histologically analyzed. Subsequently, the samples were examined with Raman spectroscopy to assess the diversity of incorporated particles.

\section{Particle distribution}

Thin sections provided an overview of the main structures and the distribution of

299 particles within sponge bodies. Incorporated particles were located and identified with 300 polarized light microscopy using TPE 3D imaging and Raman spectroscopy. Choanocyte 301 chambers were difficult to distinguish from the mesohyl and canals despite the staining.

302 Moreover, no particles were found inside the visible choanocyte chambers; only particles 
surrounding choanocyte chambers were observed in both Tethyid species. Therefore, no further statistical analysis was conducted on choanocyte chambers. system, the mesohyl, the ectosome and the fibrous skeleton, depending on the species (Fig. 1, embedded in the surrounding tissue (Fig. 2, Supplementary material Fig. S3). All specimens incorporated particles in the mesohyl and the ectosome. Moreover, $73 \%$ of the specimens, independently of the skeletal material, had some particles in the aquiferous system; the clades

311 Ircinia I did not contain particles in their canals. All specimens of the subclass Keratosa 312 incorporated particles in their skeletal spongin fibers (e.g., Fig. 2D), whereas 313 heteroscleromorphs did not in relation to their spiculated skeleton (Fig. 1). abundance (the higher the light intensity, less dense the particle cover), in comparison to the

316 density of particles accumulated in spongin fibers and/or the ectosome (Fig. 1). Moreover,

317 thorough microscopy analyses reveal a majority of small particles $(<50 \mu \mathrm{m})$ present in the 318 mesohyl/aquiferous system and accumulated in the ectosome (Fig. 1, 2). Larger particles $(>50$

$319 \mu \mathrm{m}$ ) were observed in spongin primary fibers of keratose sponges (Fig. 1, 2). Only specimens 320 from the clade Ircinia I incorporated large particles in all three structures. The size of uptaken 321 particles between Ircinia species differed although they belong to the same genus. In fact, the 322 clade Ircinia II reflected Carteriospongia's particle size pattern. Measured particles on the 323 filters varied in size, with a diameter ranging from $5 \mu \mathrm{m}$ to approximately $200 \mu \mathrm{m}$, which are 324 equivalent in size to the particles measured in situ (Fig. 2). The size of the particle may 325 therefore indicate in which structure particles might have been incorporated in relation to Fig. 326 1, for example, larger particles in Keratosa are more likely to come from the fiber network than 
the mesohyl (Fig. 1, 2). The fine fraction $(<200 \mu \mathrm{m})$ was absent from the beach sand sample, where only coarse particles ( $>500 \mu \mathrm{m}$ diameter) were observed.

\section{Particle diversity}

A total of 1,686 particles were measured on 15 filters (between 103 and 110 particles per filter). Across all measured particles on the filters, 34 different spectra were identified, of which 22 were associated to a single material or pigment (aragonite, calcite, amorphous calcite, quartz, ß-quartz, anatase, feldspar, graphite, magnetite, mackinawite, ferrosilite, cotunnite, hematite, riebeckite derivative, polystyrene, cotton, carbon, Argopecten irradians shell, red

Tab. S4). The 12 remaining spectra are polymineralic particles and were interpreted as a mixture of two different materials (e.g., aragonite + quartz). Tab. 1 illustrates the variability and diversity of the scarce incorporated compounds between the different species.

Inorganic compounds.

Independent of their identical chemical formula (i.e., $\mathrm{CaCO}_{3}$ ), calcite was

344 distinguishable from aragonite with Raman spectroscopy due to a different crystal, i.e., trigonal 345 vs. orthorhombic, respectively. This crystallographic change is translated into different vibrational bands in the lattice modes. Calcite and aragonite showed similar vibrational bands

347 around 150, 705 and $1085 \mathrm{~cm}^{-1}$, but calcite had a band at ca. $280 \mathrm{~cm}^{-1}$, whereas aragonite had 348 one at ca. $205 \mathrm{~cm}^{-1}$. Quartz was characterized with a vibrational band at $460 \mathrm{~cm}^{-1}$, related to 349 the Si-O-Si bond. Carbonate phosphate showed two weak vibrational bands at ca. $960 \mathrm{~cm}^{-1}$ 350 (phosphate; $\mathrm{PO}_{4}{ }^{3-}$ ) and $1075 \mathrm{~cm}^{-1}$ (carbonate; $\mathrm{CO}_{3}{ }^{2-}$ ). The latter is very close to the strongest 351 vibrational band observed for calcite and aragonite (ca. $1085 \mathrm{~cm}^{-1}$ ), also associated with $\mathrm{CO}_{3}{ }^{2-}$ 
352 . Feldspar was distinguished by three vibrational bands: ca. 290, 480 and $510 \mathrm{~cm}^{-1}$ (silica; Si), and anatase by one main band at ca. $140 \mathrm{~cm}^{-1}$. The D-band (ca. $1350 \mathrm{~cm}^{-1}$ ) and G-band (ca. $1580 \mathrm{~cm}^{-1}$ ) are indicative for carbon-based materials, such as carbon, graphene and graphite. Given the band shape and ratio between both lines (Roscher et al. 2019), we identified the compounds as carbon and graphite (Fig. 3).

\section{Organic compounds.}

Polystyrene was also measured for two particles during a random search pattern.

Particles, such as cotton and blue colored particles, were found during a target search pattern

(Tab. 1). Some of these materials potentially come from man-made products, which is discussed in detail below. One specimen of Carteriospongia sp. (4.6 mg dry weight) and one of Ircinia I (6.3 mg dry weight) contained polystyrene at a concentration of 0.217 and 0.159 particle/mg, respectively. Four specimens from the Genus Iricnia (4.8, 4.9, 6.3 and $6.5 \mathrm{mg}$ dry weight, respectively) were found with cotton at concentrations between 0.154 and 0.612 particle/mg.

Pigmented compounds.

The Raman signature of a white and a red sclerite of Tubipora musica (GW1858) showed that the red pigment signal generally (peaks at 1326 and $1511 \mathrm{~cm}^{-1}$ ) covers all vibrational bands of calcite (ca. 280 and $1085 \mathrm{~cm}^{-1}$ ). However, this red pigment (type I), found also in red aragonitic particles (e.g., red type I + aragonite), did not overtake the vibrational bands of aragonite (ca. 150 and $1085 \mathrm{~cm}^{-1}$ ), ubiquitous across all samples. A second and third red pigments were also detected with Raman spectroscopy, showing peaks at 1161 and 1523 $\mathrm{cm}^{-1}$ and at 1118 and $1502 \mathrm{~cm}^{-1}$, respectively. Red pigment type III is slightly shifted compared to the type I and II (Fig. 3). Finally, blue-pigmented particles were observed on the filter of two 
specimens from the clade Tethyid I (11.0 and $8.5 \mathrm{mg}$ dry weight, respectively) at a concentration of 0.091 (type I) and 0.118 (type II) particle/mg.

\section{Mineral ratios.}

Aragonitic and calcitic particles were identified in all observed structures. Tethyid clades did not only incorporate minerals, but also a considerable amount of particulate organic matter (Fig. 2C, D). Keratosa specimens incorporated on average $68 \%$ aragonite and $25 \%$ calcite, whereas Heteroscleromorpha specimens had 59\% and 30\%, respectively (Fig. 4). The aragonite-calcite median ratio of Tethyid I was 1.875, Tethyid II 2.462, Cartegiospongia 2.680, Ircinia I 2.310 and Ircinia II 2.783. Although all specimens had a higher aragonite-calcite ratio on average than that of the beach sand (ratio $=1.735)$, no species had significantly different particle ratio compared to one another and to the sand sample (ANOSIM: $P=0.067$ ) as well as between the subclasses (ANOSIM: $P=0.392$ ) based on the Analysis of Similarity (Fig. 5C, D). Specimens were also compared on their aragonite-calcite ratio according to the location they were collected, i.e., Coral Eye house reef South or north. The Analysis of Similarity also indicates that the particle ratio did not significantly vary between the sampling sites (ANOSIM: $P=0.620)($ Fig. 5E).

Other than aragonite and calcite, $<2 \%$ of quartz was measured across all clades; it was however not present in the beach sand. However, $4 \%$ of the coarse grains in the beach sand sample was feldspar, which was also identified in Carteriospongia and both Tethyid clades (Tab. 1). Carbonate phosphate and titanium oxide (anatase) were respectively measured on Ircinia II and Tethyid II filters (Tab. 1). Anatase was found at concentrations of 0.208 and 0.345 particle/mg. Most abundant polymineralic particles observed across the samples were quartz + aragonite and quartz + anatase, although both of them found in low concentrations (Tab. 1). The Analysis of Similarity suggests that the species have no preference on the material 
to be incorporated, because the species did not have significantly different material assemblage composition (ANOSIM: $P>0.05)$.

\section{DISCUSSION} and spongin fibers of keratose sponges than in the mesohyl. No particles were observed in

411 choanocyte chambers, but only surrounding them in Tethyid specimens. Embedded foreign

412 particles were of larger size in keratose spongin fibers, whereas generally smaller than $50 \mu \mathrm{m}$

413 in the mesohyl and the ectosome, as confirmed with TPE analysis. Keratose and

414 heteroscleromorph sponges had a different aragonite-calcite ratio in comparison to the beach

415 sand sample. However, no species preferentially incorporated particles of particular material

416 type. A wide range of different particles were present in low ratios on the filters $(<3 \%)$, such

417 as feldspar, quartz, carbonate phosphate, red pigments and composites. Moreover, several 418 particles are most certainly of anthropogenic origin, i.e., cotton, titanium dioxide, plastic and

419 blue pigments, at ratios between 0.091 to 0.612 particle/mg dry sponge tissue.

\section{Incorporation of foreign particles}

The capture and retention of foreign particles are common practice amongst sponges, especially noticeable within members of the subclass Keratosa, for instance species of the

424 genus Dysidea embed particles in their spongin fibers (Willenz and van de Vyver 1982;

425 Teragawa 1986a; Cerrano et al. 2007). The pathway most likely used to incorporate coarse particles in the core of spongin fibers is the endocytosis by exopinacocytes (Willenz and van 
de Vyver 1982; Teragawa 1986a). The diffusion of foreign particles through the ectosome towards the mesohyl in keratose specimens from Bangka Island suggests a particle transfer from the superficial region of the sponge towards the inner one. These findings indicate that

430 the mesohyl serves as a transit zone for particle transport in keratose demosponges. Similar

431 pathways are likely used by heteroscleromorph demosponges; however, patterns observed in our study show differences between accumulation areas. Indeed, Tethyid clades present a thick and dense ectosome composed of organic and inorganic particles of size equal to or smaller than $50 \mu \mathrm{m}$ diameter. Similar particles also aggregate around choanocyte chambers, which indicates that particles are incorporated via both processes, i.e., captured by the exopinacocytes and absorbed or phagocytized by choanocytes. Consequently, sponges tend to select more voluminous particles $(>50 \mu \mathrm{m})$ to support their skeleton in keratose demosponges and to retain smaller particles $(<50 \mu \mathrm{m})$ in the ectosome in spiculated demosponges (Teragawa 1986b; Cerrano et al. 2007). Based on these findings, microparticulate pollutants are incorporated by sponges either in skeletal fibers or the ectosome, or both depending on the particle size.

\section{Origins of inorganic particles}

Scarce minerals. upon volcanic-sedimentary basement and underlain by oceanic crust” (Kavalieris et al. 1992); in other words, geological formations are mainly composed of basaltic and andesitic rocks

450 including minerals such as feldspar (Carlile et al. 1990). Intrusion of granite and granodiorite coupled with small localized quartz diorite stocks in the basement of North Sulawesi mainland 
452 (Kavalieris et al. 1992) might explain the abundance of fine grained quartz particles reported

453 in all analyzed sponges. Moreover, Manado city and further North, i.e., Bunaken and Bangka

454 islands, is formed with andesitic epiclasts, reworked basaltic rocks rich in quartz and feldspar

455 minerals (Kavalieris et al. 1992). Slightly further North of Bangka island, a modern ferric

456 formation was described by Heikoop et al. (1996) near Mahengetang island (Indonesia). The

457 latter, coupled with commonly reported iron-associated precipitations in shallow-marine

458 environments (Taylor and Macquaker 2011), provide an explanation of the presence of

459 different iron minerals in our samples. Ions of trace metals, such as $\mathrm{Pb}^{2+}$, were measured on the

460 coastal area of East Java Province (Indonesia), which might explain the presence of mineral

461 cotunnite encountered in our samples (Apriani et al. 2018). Although a wide range of different

462 mineral compounds have been identified in our study, e.g., magnetite, ferrosilite, cotunnite and

463 mackinawite, the sediment composition on, for example, the Spermonde shelf (South Sulawesi,

464 Indonesia) revealed only hard parts of calcifying organisms (aragonite and calcite) of sizes

465 greater than $250 \mu \mathrm{m}$ (Janßen et al. 2017). The latter findings however correlate with the

466 abundance of calcium carbonate found in our sand and sponge samples. Although not

467 significantly different from the aragonite-calcite ratio of the beach sand, all sponges

468 incorporated on average more aragonite. We speculate that the surrounding fine suspended

469 matter in the reef might be therefore slightly different than the matter sedimenting in the

470 intertidal range. Nonetheless, our study unravels a wide variety of very fine inorganic particles

$471(<200 \mu \mathrm{m})$ present in the immediate benthic environment, but absent in the sediment (or

472 undetectable with traditional sediment sampling method).

474 Red pigments.

475 Multiple red, orange and pink colored particles that are referred to as "red

476 biomineralization" were present in the beach sand sample and in the 15 specimens analyzed 
477 for their particle content. Red pigments of three types (I, II and III) were observed with Raman

478 spectroscopy (Fig. 3). Type I highly resembles the signature of red sclerites from Tubipora

479 musica. Tubipora species were indeed an important part of the octocoral fauna at Coral Eye

480 house reef (EB Girard, personal observation). Bergamonti et al. (2011) studied different Raman

481 spectra of various hard-skeleton animals, including Tubipora musica and Corallium rubrum,

482 and obtained the same vibrational bands as the red pigment type I. The hydrocoral Stylaster sp.

483 also exhibits a red pigment, which is identical to that of type II measured on some filters

484 (Bergamonti et al. 2011). Bergamonti et al. (2011) and Thompson et al. (2015) advance that

485 this pigment is linked to carotenoids. The red pigment type I comes from non-methylated

486 polyenes, whereas type II is likely the result of methylated polyenes (Bergamonti et al. 2011;

487 Thompson et al. 2015). However, the origin of these pigments is yet not fully understood. The spectrum of the red pigment type III resembles that of the shell of the bay scallop Argopecten irradians (Thompson et al. 2014, 2015). However, this bivalve species is mainly known from

490 the East coast of the United States. Other coral reef organisms from Indonesia most probably

491 have an analogous Raman spectrum, which explains its identification in a few sampled 492 sponges.

\section{Origins of micropollutants}

A wide range of different materials was observed in sponges from Bangka Island. On the one hand, they are autochthonous and reflect geological formations, e.g., quartz and

497 feldspar (Carlile et al. 1990; Kavalieris et al. 1992), and reef assemblages, e.g., tunicates and reef-building corals (Yamano et al. 2000; Bergamonti et al. 2011; Łukowiak 2012), of the surroundings. Indeed, slow weathering and erosion processes generate the detachment of

500 particles that compose, together with the reef's coral sand production, most of today's Bangka 
501 Island sand. On the other hand, they are allochthonous and foreign to the natural environment, such as titanium dioxide, blue-pigmented particles and microplastics.

\section{Titanium dioxide.}

Titanium dioxide $\left(\mathrm{TiO}_{2}\right)$ forms in three minerals: anatase, brookite and rutile, which have differing crystallographic organization (Balachandran and Eror 1982). This aspect 1982). Titanium oxides can naturally accumulate in the sand subsequent to weathering of the

510 titanium-bearing mineral ilmenite by underground water (Premaratne and Rowson 2003).

511 However, anatase is also used as a white pigment, i.e., PW6 (titanium white), in automotive 512 paints (Zięba-Palus and Michalska 2014), pharmaceutical coatings (Alexander 2008),

513 thermoplastic resin (Kitamura and Mitsuuchi 1996) and archeological paints (Middleton et al.

514 2005). Nanoparticulate anatase, together with rutile, is also extensively used for its chemical 515 properties and UVB protective behavior in sunscreens (Yue et al. 1997; Jaroenworaluck et al. 516 2006; Serpone et al. 2007). Hence, anatase particles found in sponges from Coral Eye house

517 reef might as well come from the degradation of anthropogenic anatase-containing products, 518 and not only from natural sources. The effect of nanoparticulate anatase on health was 519 investigated in mice and corals since it infiltrated the natural environment and its 520 ecotoxicological impact, although not fully understood, concluded little to no effects on health 521 at low concentrations (Duan et al. 2010; Adler and DeLeo 2020).

\section{Blue pigments.}

Particles of highly similar blue color to the human eye were incorporated in two 
signatures. The main vibrational bands were also measured by Zieba-Palus and Michalska

527 (2014); the authors identified Raman vibrational bands of blue pigments used in car paints. The

528 blue pigment Type I is most probably a mix between the pigment PV23 (dioxazine violet) and

529 PB15 (phthalocyanine 15) and the blue pigment Type II PB15, according to the findings of

530 Zieba-Palus and Michalska (2014). These synthetic organic pigments might also be used in

531 marine coating or recreational painting (Bouchard et al. 2009). Because the Raman vibrational

532 bands of the pigments overwrite that of its polymer composition, it is not possible to identify

533 the material of the particle. However, the pigment PB15 was previously recorded as a dye

534 associated with microplastics isolated from the soft tissue of bivalves (van Cauwenberghe and

535 Janssen 2014) and intertidal textile fibers (Girard et al. 2020).

536

\section{Textiles and microplastics.}

High tides and winds bring large quantities of marine debris, including plastics and textiles, on Bangka Island (EB Girard, personal observation; (Giebel 2018) unpublished report). The litter lands on beaches, where the highest degradation rate of plastic has been reported (Andrady 2017). Coral Eye Resort volunteers clean the beach daily, however this is not done systematically all around the island yet, nor on proximal coast lines (EB Girard,

543 personal observation). Consequently, eight microparticles were herein identified as cotton $(\mathrm{n}=$

544 6) or polystyrene $(n=2)$ in all sampled keratose species. Cotton has also been reported to be

545 the most observed fabric in environmental dust, as fibers in the atmosphere, but also in the

546 intertidal zone (Dris et al. 2016, 2017; Girard et al. 2020). Nevertheless, some of these particles

547 may also originate from the cloth made of cotton that was used to dry glass dishes to avoid

548 plastic contamination of the samples. Polystyrene is one of the three most abundant

549 microplastic materials reported at sea, together with polyethylene and polypropylene (Andrady

550 2017; Auta et al. 2017). Our results are further supported by the findings of Ling et al. (2017), 
who estimated that the concentration of microplastic particles in the sediment reaches up to 0.4 concentration in a size range ca. 60-400 $\mu \mathrm{m}$ (Ling et al. 2017), which is concordant with the particle size incorporated by the sponge exopinacoderm. Because sponges can pump several decades to hundreds of liters per day (Leys et al. 2011) and microparticles deposit on their ectosome, Bangka specimens indeed incorporated microplastics.

\section{Sponges as bioindicators}

Sponges are potentially ideal local bioindicators because they are sessile animals and Soest 1989, 1990; Cerrano et al. 2002, 2006; Bell and Smith 2004; de Voogd et al. 2006, 2009; material Fig. S4). Furthermore, a recent study identified sponges as a good monitor to record environmental stress (Carballo et al. 1996), water quality (Mahaut et al. 2013), and multiple pollutants, e.g., heavy metal pollution (Selvin et al. 2009; Venkateswara Rao et al. 2009) and polychlorobiphenyl (Perez et al. 2003). Collection sponges have also been recently surveyed for fibrous microplastics (Modica et al. 2020).

\section{Extrapolation to realistic micropollutant concentrations.}

Based on our results, sampled sponges did not preferentially incorporate particles of 
variation of surrounding microparticles. At a concentration higher than 0.1 particle/mg of dry

be incorporated by sponges weighing more than $100 \mathrm{~g}$ (dry weight). Similar approximations can derive from the results regarding abundance of blue-pigmented particles, cotton and titanium dioxides in the spiculated demosponge Tethyid species. Because sponges can weigh particles in sponge tissue is likely to reveal more microplastics and other particles derived from anthropogenic products.

Sponges are therefore efficient sediment traps, recording the diversity of the matter in the ambient water as they are able to register this diversity to the finest grain $(<200 \mu \mathrm{m})$, otherwise difficult to recall solely based on sand samples (Janßen et al. 2017), as observed in this study. Such biological monitors also provide information over a time window, whereas traditional net tows represent only a single point in time (Lindeque et al. 2020). Furthermore, in sediment traps, the fine fraction is washed away by currents, leading to biases in the actual to biomonitor micropollutants, such as particles putatively originating from anthropogenic products (e.g., microplastics).

\section{Outlook}

As sponges incorporate micropollutants from their surroundings, a sample of sponge 
601 provides a first assessment on the particle diversity in sponges. For future research on the topic,

602 we suggest analyzing a large amount of tissue and particles by, for instance, dissolving the

603 carbonates, which will provide a higher resolution of the diversity of scarce particles

604 incorporated by sponges.

605 Further hypothetical outcomes arise as sponges incorporate micropollutants, for 606 instance toxins associated with these microparticles can leach, impacting sponge development

607 and pumping capacity (Hill et al. 2002). Likewise, microbial pathogens hitchhiking on, for

608 example, microplastics may negatively affect sponges (Taylor et al. 2007), both of which will

609 have a direct impact on the ecosystem they inhabit. Keratose demosponges may also use

610 particulate micropollutants to build their skeleton and support their growth, creating temporary

611 sinks or an expressway to enter the marine food chain through spongivores. On a more positive

612 note, sponges likely host degrading bacteria able to remineralize certain micropollutants (Lee

613 et al. 2001), taking the sponge loop theory to the next level.

614 

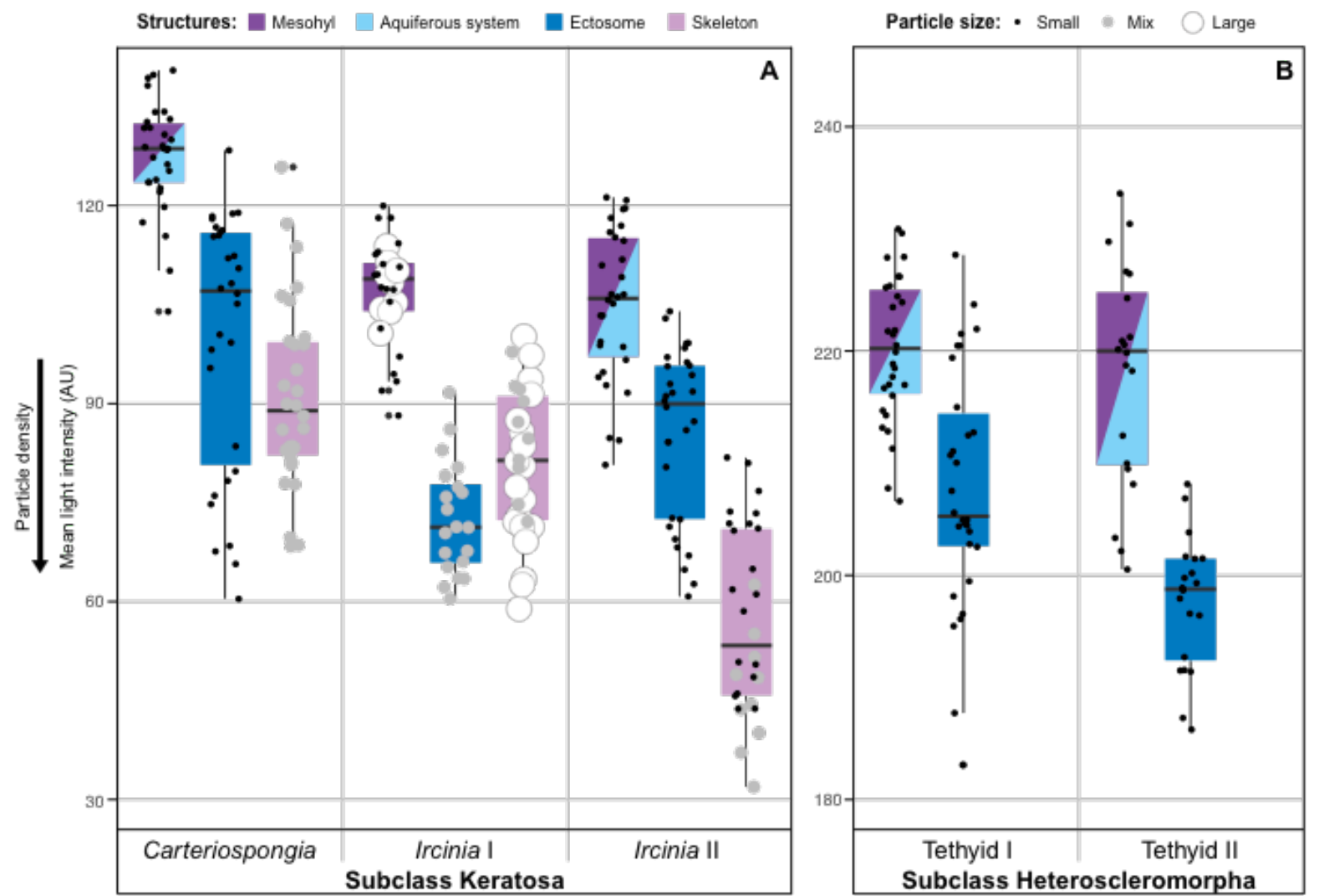

616 Figure 1. Particle distribution amongst sampled sponges and their abundance in tissue

617 structures as derived from brightfield imaging. A) Subclass Keratosa, B) subclass

618 Heteroscleromorpha. The lower the intensity, i.e., absorption of the specimen body, the higher

619 the number of particles in the structure; the aquiferous system was not differentiated from the

620 mesohyl in cases where particles were present in the aquiferous system. Particle size is

621 represented by the size and color of the dots (i.e., black small dots for a majority of particles $<$

$62250 \mu \mathrm{m}$, white large dots for a majority of particles $>50 \mu \mathrm{m}$ and gray medium dots for a more

623 or less equal presence of small and large particles). Color code: skeleton in lila, aquiferous

624 system in cyan, mesohyl in purple, ectosome in blue. The black horizontal line inside the boxes

625 represents the median intensity value of the data. The mean light intensity (y-axis) is given in

626 an arbitrary unit (AU). Note: relative intensity within the same subclass can be compared,

627 however not between the subclasses as the scale used was different. 
bioRxiv preprint doi: https://doi.org/10.1101/2020.05.26.116012; this version posted May 28, 2020. The copyright holder for this preprint (which was not certified by peer review) is the author/funder, who has granted bioRxiv a license to display the preprint in perpetuity. It is made available under aCC-BY-NC-ND 4.0 International license.
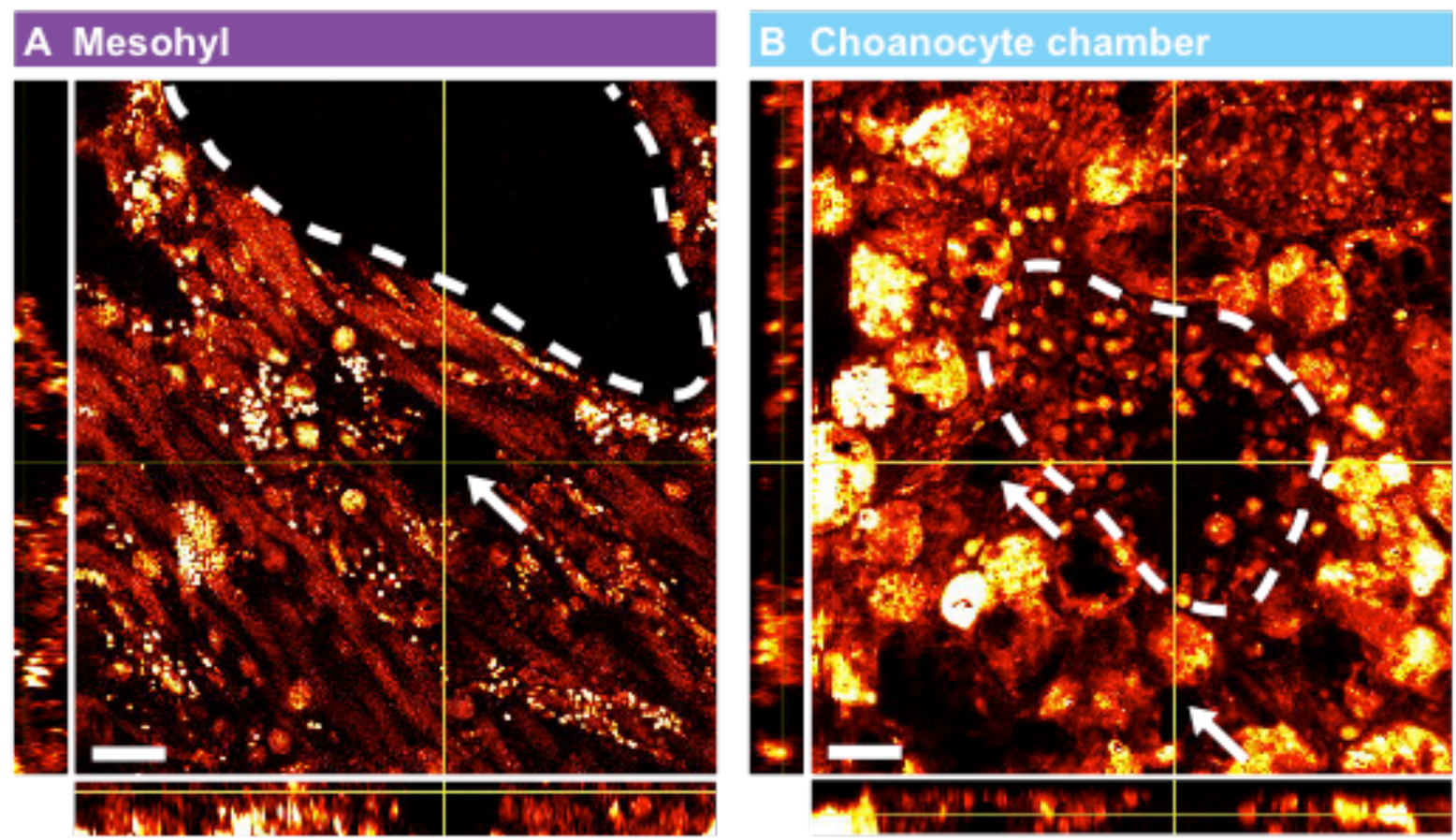

\section{Ectosome}
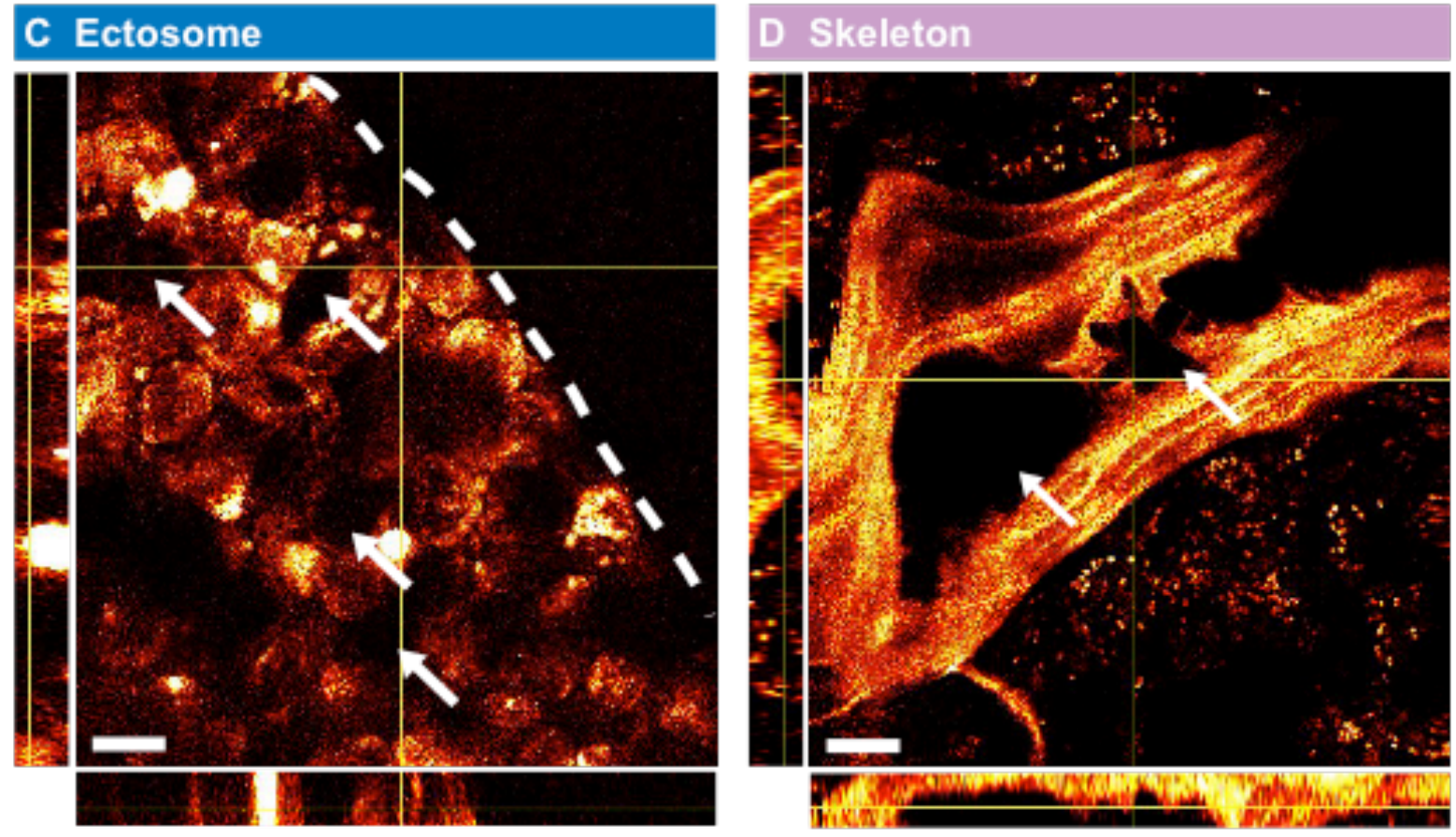

631 Figure 2. Two-photon images of three-dimensional sponge tissue sections with embedded

632 foreign particles. The auto-fluorescence of the organic tissue material serves as imaging

633 contrast compared to inorganic particles that are non-fluorescent. XZ and YZ projections

634 through the 3D image stack are depicted aside of each XY projection (brightfield images are 
635 shown in Supplementary material Fig. S3). Exogenous particles are embedded in the tissue

636 (marked with white arrows) and are found A) in the mesohyl of Ircinia sp. (the canal is circled

637 with a dashed line), B) surrounding the choanocyte chamber of Tethyid sp. (circled with a

638 dashed line), C) at the ectosome of Tethyid sp. (the dashed line separates the outermost part of

639 the sponge tissue), and D) in spongin fibers of Carteriospongia sp.. Z-scan ranges are $18 \mu \mathrm{m}$

640 and scale bars are $20 \mu \mathrm{m}$.

641 Color printed required; 2-column fitting image

642 
bioRxiv preprint doi: https $/ /$ doi org/10.1101/2020 05 26.116012; this version posted May 28, 2020. The copyright holder for this preprint (which was not certified by peer review) is the author/funder, who has granted bioRxiv a license to display the preprint in perpetuity. It is made available under aCC-BY-NC-ND 4.0 International license.
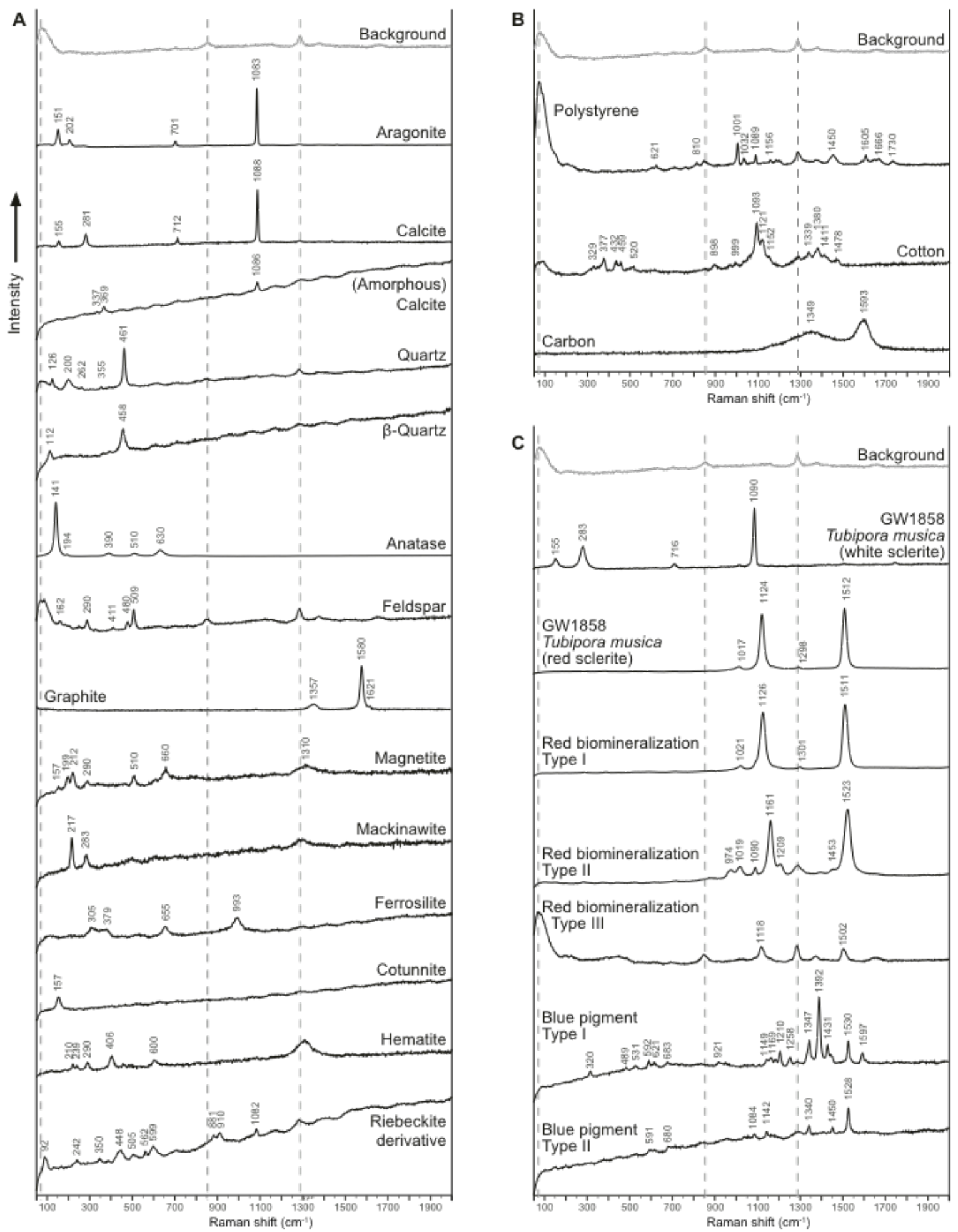

644 Figure 3. Raman spectra of incorporated particles $(n=1686)$. Mix spectra are not included, as

645 they are a combination of two different minerals illustrated above. A) inorganic spectra. B)

646 organic spectra. C) spectra associated with pigments. Red biomineralization spectra are

647 compared to GW1858 (octocoral Tubipora musica red and white sclerites). Numbers over the 
bioRxiv preprint doi: https://doi.org/10.1101/2020.05.26.116012; this version posted May 28,2020 . The copyright holder for this preprin (which was not certified by peer review) is the author/funder, who has granted bioRxiv a license to display the preprint in perpetuity. It is made available under aCC-BY-NC-ND 4.0 International license.

\section{Black-and-White printed; 2-column fitting image}

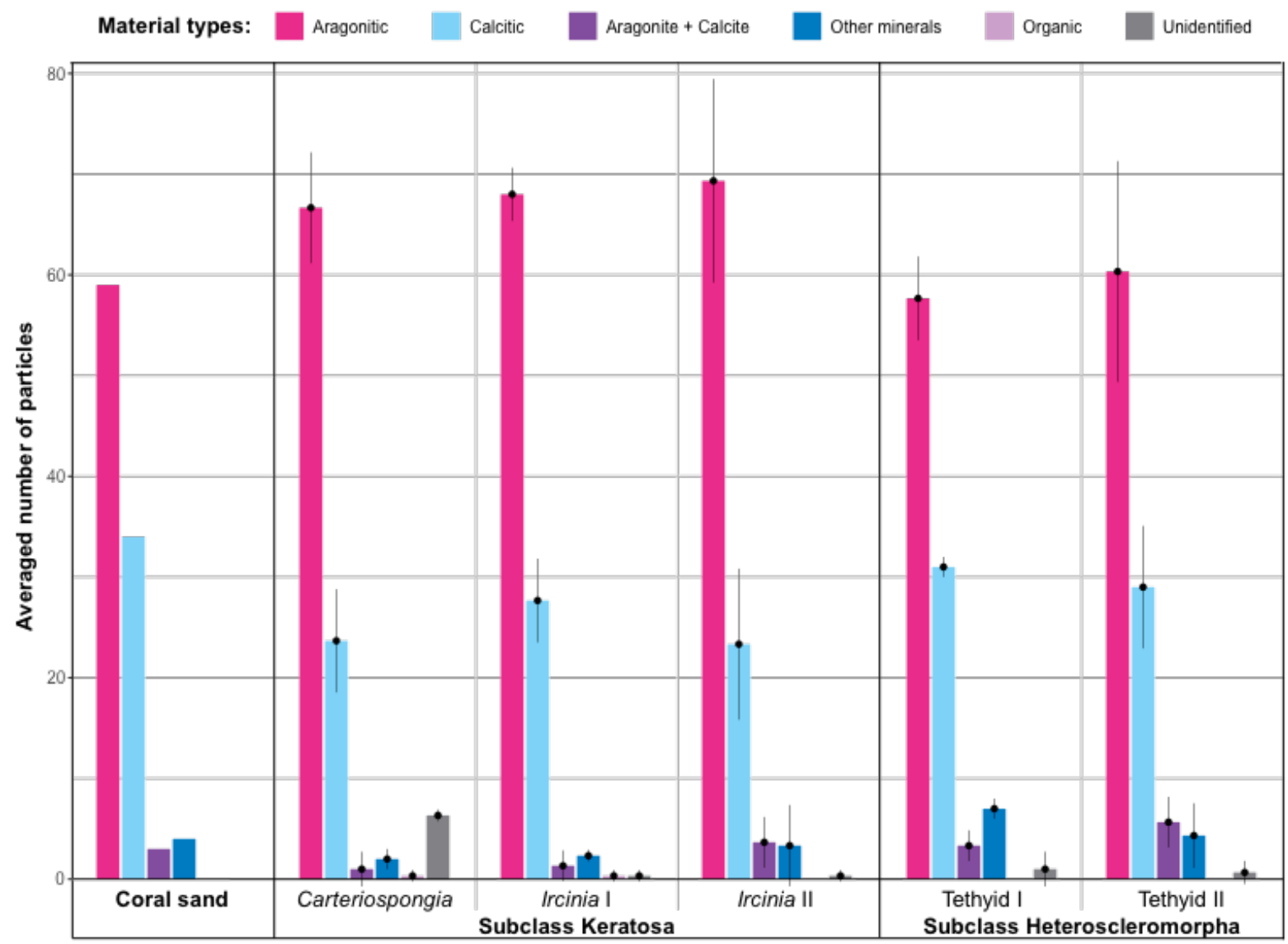

653 Figure 4. Diversity of materials among sampled sponges. Particle diversity from resulting

654 Raman measurements of 100 randomly selected particles per sample. Each species accounts

655 for 3 samples, and particle counts were averaged per clade (pink: aragonitic; cyan: calcitic; 656 purple: aragonite + calcite; blue: other minerals; lila: organic; gray: unidentified). Error bars

657 illustrate the variation in number of particles per category between the specimens of the same 658 species. The category "Unidentified" results from low quality spectra, which could not be 659 associated with any known material.

660 Color printed required; 2-column fitting image 

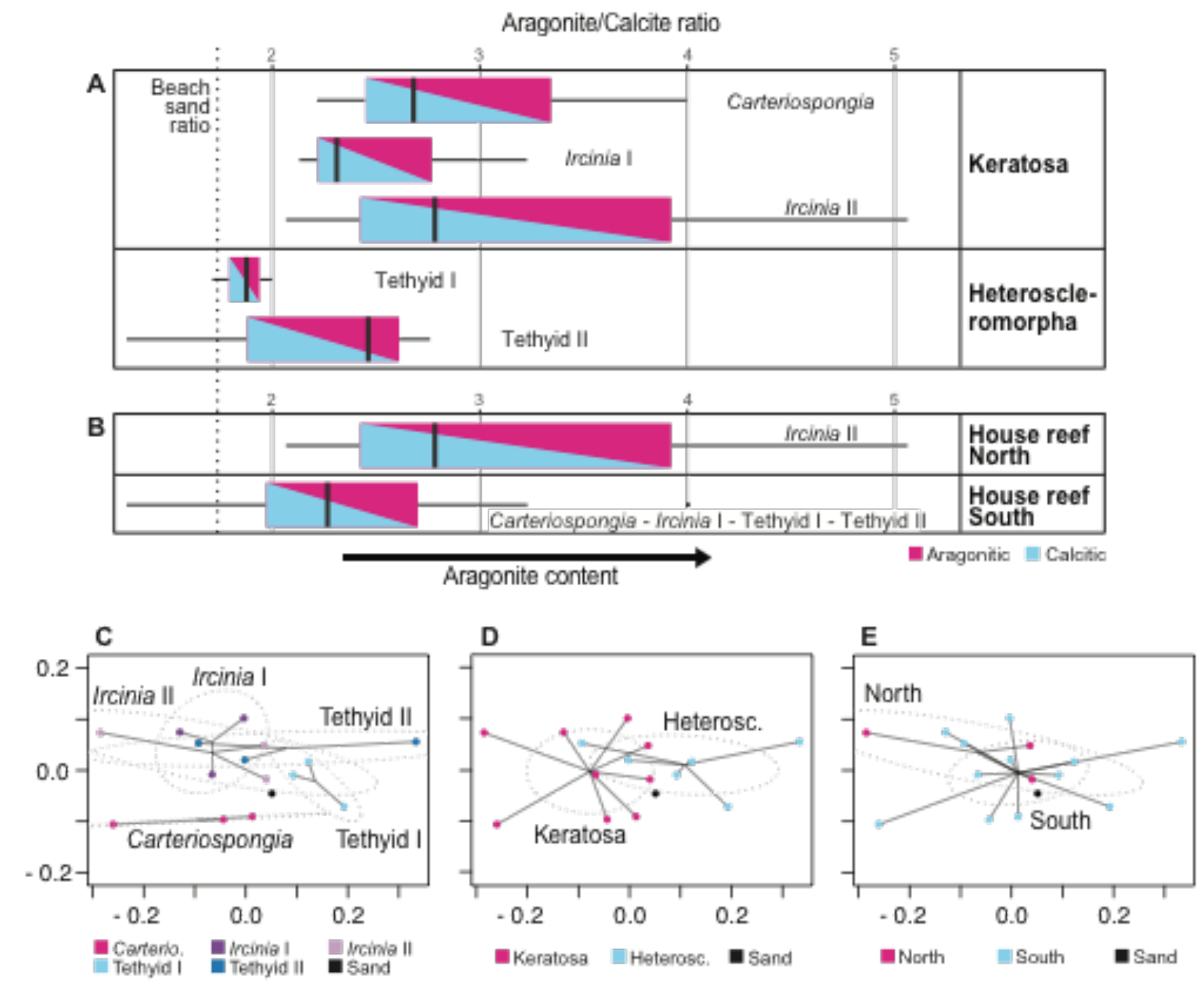

663 Figure 5. Aragonite to calcite ratio A) at the species level and B) according to the sampling

664 site. The beach sand sample ratio (1.735) is indicated with the dotted vertical line. Non-metric

665 multidimensional scaling (NMDS) plots C) at the species level, D) at the subclass level and E)

666 according to the sampling site, displaying the differences between the foreign particle

667 assemblage composition. Dashed gray ellipses represent the $99 \%$ confidence interval. Note:

668 the Analysis of Similarity indicates no significant differences between the samples at all three

669 comparison levels (ANOSIM: $P>0.05$ ).

670 Color printed required; 2-column fitting image

671

672 
673 Table 1. Number of scarce inorganic, organic and pigmented particles, which have been

674 identified with Raman spectroscopy, including polyminerals but excluding calcitic or

675 aragonitic particles. Numbers of articles and dry weight were summed between the specimens

676 of the same species. Total dry weight of digested sponge tissue and the number of potentially

677 anthropogenic particles are highlighted in gray.

Number of particles found per species

\begin{tabular}{|c|c|c|c|c|c|c|c|c|c|c|c|}
\hline & \multirow{2}{*}{\multicolumn{2}{|c|}{ Carteriospongia }} & \multirow{2}{*}{\multicolumn{2}{|c|}{ Ircinia I }} & \multirow{2}{*}{\multicolumn{2}{|c|}{ Ircinia II }} & \multirow{2}{*}{\multicolumn{2}{|c|}{ Tethyid I }} & \multirow{2}{*}{\multicolumn{2}{|c|}{ Tethyid II }} \\
\hline & & & & & & & & & & & \\
\hline \multicolumn{2}{|c|}{$\begin{array}{r}\text { Total dry weight of } \\
\text { tissue }\end{array}$} & \multicolumn{2}{|c|}{$12.5 \mathrm{mg}$} & \multicolumn{2}{|c|}{$18.7 \mathrm{mg}$} & \multicolumn{2}{|c|}{$14.8 \mathrm{mg}$} & \multicolumn{2}{|c|}{$28.1 \mathrm{mg}$} & \multicolumn{2}{|c|}{$18.6 \mathrm{mg}$} \\
\hline & Search pattern & Random & Target & Random & Target & Random & Target & Random & Target & Random & Targe \\
\hline \multirow{16}{*}{$\begin{array}{l}\stackrel{0}{E} \\
\bar{\sigma} \\
\stackrel{0}{0} \\
\subseteq\end{array}$} & Quartz & 2 & --- & 3 & --- & 3 & --- & 8 & --- & 2 & --- \\
\hline & ß-Quartz & --- & --- & --- & --- & --- & --- & -- & 1 & --- & 2 \\
\hline & Feldspar & 1 & --- & --- & --- & --- & 1 & 3 & --- & 3 & --- \\
\hline & $\begin{array}{l}\text { Carbonate } \\
\text { phosphate }\end{array}$ & --- & --- & --- & --- & 4 & --- & --- & --- & --- & -- \\
\hline & Anatase & --- & --- & --- & --- & --- & 1 & --- & --- & 2 & --- \\
\hline & $\begin{array}{l}\text { Riebecktite } \\
\text { derivative }\end{array}$ & --- & --- & --- & --- & --- & --- & --- & --- & 1 & --- \\
\hline & Magnetite & --- & --- & --- & --- & --- & --- & --- & --- & 1 & --- \\
\hline & Ferrosilite & --- & --- & 2 & 1 & --- & --- & 1 & --- & --- & --- \\
\hline & Hematite & --- & -- & --- & --- & --- & 1 & 1 & 1 & -- & -- \\
\hline & Cotunnite & 1 & -- & --- & -- & --- & --- & -- & --- & -- & 1 \\
\hline & Graphite & --- & --- & --- & --- & --- & --- & -- & --- & --- & 1 \\
\hline & Mackinawite & --- & --- & --- & --- & --- & --- & --- & 1 & --- & 2 \\
\hline & $\begin{array}{l}\text { Quartz + } \\
\text { Aragonite }\end{array}$ & 1 & --- & --- & --- & 1 & --- & 2 & --- & 1 & --- \\
\hline & $\begin{array}{l}\text { Quartz + } \\
\text { Anatase }\end{array}$ & --- & --- & --- & --- & 1 & --- & 3 & --- & 1 & 1 \\
\hline & $\begin{array}{l}\text { Anatase + } \\
\text { Feldspar }\end{array}$ & 1 & --- & 1 & --- & --- & --- & --- & --- & 1 & --- \\
\hline & $\begin{array}{l}\text { Anatase + } \\
\text { Calcite }\end{array}$ & -- & -- & --- & -- & --- & -- & 1 & --- & 1 & --- \\
\hline \multirow{3}{*}{ 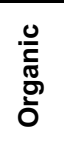 } & Carbon & --- & -- & --- & --- & --- & --- & --- & 1 & --- & 2 \\
\hline & Cotton & --- & --- & --- & 2 & --- & 4 & --- & --- & --- & --- \\
\hline & Polystyrene & 1 & -- & 1 & -- & -- & --- & -- & -- & -- & -- \\
\hline \multirow{3}{*}{ 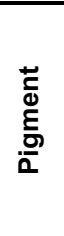 } & $\begin{array}{l}\text { Red pigment } \\
\text { type III }\end{array}$ & --- & 3 & 1 & --- & --- & --- & --- & --- & --- & --- \\
\hline & $\begin{array}{l}\text { Blue pigment } \\
\text { type I }\end{array}$ & --- & --- & -- & -- & --- & --- & --- & 1 & --- & --- \\
\hline & $\begin{array}{l}\text { Blue pigment } \\
\text { type II }\end{array}$ & --- & --- & --- & --- & -- & --- & --- & 1 & --- & -- \\
\hline
\end{tabular}

679 Black-and-White printed; 2-column fitting image 


\section{ACKNOWLEDGEMENTS}

682

We thank the Indonesian authorities for providing the research visa and permit 683 (research permit holder: Elsa Girard; SIP no.: 97/E5/E5.4/SIP/2019) to conduct the research 684 activities on Bangka Island, in collaboration with Sam Ratulangi University Manado 685 (UNSRAT, Indonesia). We thank Dirk Erpenbeck, Oliver Voigt, Anna Clerici, Marco Perin, 686 Stefanie Ries, Magdalena Wilde and Samuel Leivy Opa for helping during field work activities. 687 A last word to thank the No-Trash Triangle Initiative for tackling one of the big problems Earth 688 is facing today.

Funding: The field work was funded by Coral Eye Resort (Marco Segre Reinach), the

DAAD Hochschulpartnerschaft between the Zoologische Forschungsmuseum Alexander B03); and PL 696/4-1) is gratefully acknowledged. GW acknowledges support by LMU Munich's Institutional Strategy LMUexcellent within the framework of the German Excellence Initiative.

\section{REFERENCES}

Adler BL, DeLeo VA (2020) Sunscreen Safety: a Review of Recent Studies on Humans and the Environment. Curr Dermatol Rep. https://doi.org/10.1007/s13671-020-00284-4

Alexander R (2008) Raman spectroscopy analysis of polymorphs. In: Photonics Media. 
bioRxiv preprint doi: https://doi.org/10.1101/2020.05 26.116012· this version posted May 28,2020 . The copyright holder for this preprint (which was not certified by peer review) is the author/funder, who has granted bioRxiv a license to display the preprint in perpetuity. It is made available under aCC-BY-NC-ND 4.0 International license.

706

707

708

709

710

711

712

713

714

715

716

717

718

719

720

721

722

723

724

725

726

727

728

Apriani M, Hadi W, Masduqi A (2018) Physicochemical Properties of Sea Water and Bittern in Indonesia: Quality Improvement and Potential Resources Utilization for Marine Environmental Sustainability. J Ecol Eng 19:1-10

Auta HS, Emenike CU, Fauziah SH (2017) Distribution and importance of microplastics in the marine environment: A review of the sources, fate, effects, and potential solutions. Environ Int 102:165176

Balachandran U, Eror NG (1982) Raman spectra of titanium dioxide. J Solid State Chem 42:276-282

Becking LE, Cleary DFR, de Voogd NJ (2013) Sponge species composition, abundance, and cover in marine lakes and coastal mangroves in Berau, Indonesia. Mar Ecol Prog Ser 481:105-120

Bell JJ (2008) The functional roles of marine sponges. Estuar Coast Shelf Sci 79:341-353

Bell JJ, Smith D (2004) Ecology of sponge assemblages (Porifera) in the Wakatobi region, south-east Sulawesi, Indonesia: richness and abundance. J Mar Biol Assoc U K 84:581-591

Bergamonti L, Bersani D, Csermely D, Lottici PP (2011) The nature of the pigments in corals and pearls: A contribution from Raman spectroscopy. Spectrosc Lett 44:453-458

Bouchard M, Rivenc R, Menke C, Learner T (2009) Micro-FTIR and micro-Raman full paper study of paints used by Sam Francis. e-PS 6:27-37

Burns E, Ilan M (2003) Comparison of anti-predatory defenses of Red Sea and Caribbean sponges. II. Physical defense. Mar Ecol Prog Ser 252:115-123

Calcinai B, Bastari A, Bavestrello G, et al (2017a) Demosponge diversity from North Sulawesi, with the description of six new species. Zookeys 105-150

Calcinai B, Bastari A, Makapedua DM, Cerrano C (2017b) Mangrove sponges from Bangka Island (North Sulawesi, Indonesia) with the description of a new species. J Mar Biol Assoc U K 97:1417-1422 
bioRxiv preprint doi: https://doi.org/10.1101/2020.05 26.116012· this version posted May 28, 2020. The copyright holder for this preprint (which was not certified by peer review) is the author/funder, who has granted bioRxiv a license to display the preprint in perpetuity. It is made available under aCC-BY-NC-ND 4.0 International license.

729 Carballo JL, Naranjo SA, García-Gómez JC (1996) Use of marine sponges as stress indicators in marine ecosystems at Algeciras Bay (southern Iberian Peninsula). Mar Ecol Prog Ser 135:109_ 122

732

733

734

735

736

737

738

739

740

741

742

743

744

745

746

747

748

749

750

751

Carlile JC, Digdowirogo S, Darius K (1990) Geological setting, characteristics and regional exploration for gold in the volcanic arcs of North Sulawesi, Indonesia. J Geochem Explor $35: 105-140$

Cerrano C, Bavestrello G, Boyer M, et al (2002) Psammobiontic sponges from the Bunaken Marine Park (North Sulawesi, Indonesia): Interactions with sediments. Proc 9th Int Coral Reef Symp $279-282$

Cerrano C, Calcinai B, Di Camillo CG, et al (2007) How and why do sponges incorporate foreign material? Strategies in Porifera. In: Custódio MR (ed) Porifera research : biodiversity, innovation and sustainability. Museu Nacional, Rio de Janeiro, pp 239-246

Cerrano C, Calcinai B, Pinca S, Bavestrello G (2006) Reef sponges as hosts of biodiversity: cases from North Sulawesi. Proc 10th Int Coral Reef Symp 208-213

Darriba D, Taboada GL, Doallo R, Posada D (2012) jModelTest 2: More models, new heuristics and parallel computing. Nat Methods 9:772

de Voogd NJ, Becking LE, Cleary DFR (2009) Sponge community composition in the Derawan Islands, NE Kalimantan, Indonesia. Mar Ecol Prog Ser 396:169-180

de Voogd NJ, Cleary DFR (2008) An analysis of sponge diversity and distribution at three taxonomic levels in the Thousand Islands/Jakarta Bay reef complex, West-Java, Indonesia. Mar Ecol 29:205-215

de Voogd NJ, Cleary DFR, Hoeksema BW, et al (2006) Sponge beta diversity in the Spermonde Archipelago, SW Sulawesi, Indonesia. Mar Ecol Prog Ser 309:131-142 
bioRxiv preprint doi: https://doi org/10.1101/2020.05 26.116012; this version posted May 28,2020 . The copyright holder for this preprint (which was not certified by peer review) is the author/funder, who has granted bioRxiv a license to display the preprint in perpetuity. It is made available under aCC-BY-NC-ND 4.0 International license.

754 Dris R, Gasperi J, Saad M, et al (2016) Synthetic fibers in atmospheric fallout: A source of microplastics in the environment? Mar Pollut Bull 104:290-293

Duan Y, Liu J, Ma L, et al (2010) Toxicological characteristics of nanoparticulate anatase titanium dioxide in mice. Biomaterials 31:894-899

Eriksen M, Lebreton LCM, Carson HS, et al (2014) Plastic pollution in the world's oceans: More than 5 trillion plastic pieces weighing over 250,000 tons afloat at sea. PLoS One 9:e111913

Erpenbeck D, Aryasari R, Benning S, et al (2017) Diversity of two widespread Indo-Pacific demosponge species revisited. Mar Biodivers 47:1035-1043

Erpenbeck D, Voigt O, Al-Aidaroos AM, et al (2016) Molecular biodiversity of Red Sea demosponges. Mar Pollut Bull 105:507-514

Girard EB, Kaliwoda M, Schmahl WW, et al (2020) Biodegradation of textile waste by marine bacterial communities enhanced by light. Environ Microbiol Rep. https://doi.org/10.1111/17582229.12856

Gouy M, Guindon S, Gascuel O (2010) SeaView version 4: A multiplatform graphical user interface for sequence alignment and phylogenetic tree building. Mol Biol Evol 27:221-224

Guindon S, Dufayard J-F, Lefort V, et al (2010) New algorithms and methods to estimate maximumlikelihood phylogenies: assessing the performance of PhyML 3.0. Syst Biol 59:307-321

Hammel JU, Nickel M (2014) A new flow-regulating cell type in the Demosponge Tethya wilhelmafunctional cellular anatomy of a leuconoid canal system. PLoS One 9:e113153 setting: Mahengetang, Indonesia. Geology 24:759-762 
bioRxiv preprint doi: https://doi.org/10.1101/2020.05 26.116012· this version posted May 28,2020 . The copyright holder for this preprint (which was not certified by peer review) is the author/funder, who has granted bioRxiv a license to display the preprint in perpetuity. It is made available under aCC-BY-NC-ND 4.0 International license.

775

776

777

778

779

780

781

782

783

784

785

786

787

788

789

790

791

792

793

794

795

796

797

Hill M, Stabile C, Steffen LK, Hill A (2002) Toxic effects of endocrine disrupters on freshwater sponges: common developmental abnormalities. Environ Pollut 117:295-300

Janßen A, Wizemann A, Klicpera A, et al (2017) Sediment Composition and Facies of Coral Reef Islands in the Spermonde Archipelago, Indonesia. Frontiers in Marine Science 4:144

Jaroenworaluck A, Sunsaneeyametha W, Kosachan N, Stevens R (2006) Characteristics of silicacoated $\mathrm{TiO}_{2}$ and its UV absorption for sunscreen cosmetic applications. Surf Interface Anal $38: 473-477$

Kavalieris I, van Leeuwen TM, Wilson M (1992) Geological setting and styles of mineralization, north arm of Sulawesi, Indonesia. Journal of Southeast Asian Earth Sciences 7:113-129

Kitamura H, Mitsuuchi M (1996) Glass-reinforced thermoplastic resin compositions containing the anatase form of titanium dioxide as a white pigmenting agent. US Patent

Lee YK, Lee JH, Lee HK (2001) Microbial symbiosis in marine sponges. J Microbiol 39:254-264

Leys SP, Yahel G, Reidenbach MA, et al (2011) The sponge pump: the role of current induced flow in the design of the sponge body plan. PLoS One 6:e27787

Lindeque PK, Cole M, Coppock RL, et al (2020) Are we underestimating microplastic abundance in the marine environment? A comparison of microplastic capture with nets of different mesh-size. Environ Pollut 114721

Ling SD, Sinclair M, Levi CJ, et al (2017) Ubiquity of microplastics in coastal seafloor sediments. Mar Pollut Bull 121:104-110

Łukowiak M (2012) First Record of Late Eocene Ascidians (Ascidiacea, Tunicata) from Southeastern Australia. J Paleontol 86:521-526

Mahaut M-L, Basuyaux O, Baudinière E, et al (2013) The porifera Hymeniacidon perlevis (Montagu, 1818) as a bioindicator for water quality monitoring. Environ Sci Pollut Res Int 20:2984-2992 
bioRxiv preprint doi: https://doi.org/10.1101/2020.05 26.116012· this version posted May 28,2020 . The copyright holder for this preprint (which was not certified by peer review) is the author/funder, who has granted bioRxiv a license to display the preprint in perpetuity. It is made available under aCC-BY-NC-ND 4.0 International license.

798

799

800

801

802

803

804

805

806

807

808

809

810

811

812

813

814

815

816

817

818

819

820

Mariani S, Baillie C, Colosimo G, Riesgo A (2019) Sponges as natural environmental DNA samplers. Curr Biol 29:R401-R402

McMurray SE, Blum JE, Pawlik JR (2008) Redwood of the reef: growth and age of the giant barrel sponge Xestospongia muta in the Florida Keys. Mar Biol 155:159-171

Middleton AP, Edwards HGM, Middleton PS, Ambers J (2005) Identification of anatase in archaeological materials by Raman spectroscopy: implications and interpretation. J Raman Spectrosc 36:984-987

Modica L, Lanuza P, García-Castrillo G (2020) Surrounded by microplastic, since when? Testing the feasibility of exploring past levels of plastic microfibre pollution using natural history museum collections. Mar Pollut Bull 151:110846

Oksanen J, Blanchet FG, Friendly M, et al (2017) vegan: Community Ecology Package. Version R package version 2.4-5URL https://CRAN.R-project.org/package=vegan

Perez T, Wafo E, Fourt M, Vacelet J (2003) Marine sponges as biomonitor of polychlorobiphenyl contamination: concentration and fate of 24 congeners. Environ Sci Technol 37:2152-2158

Premaratne WAPJ, Rowson NA (2003) The processing of beach sand from Sri Lanka for the recovery of titanium using magnetic separation. Physical Separation in Science and Engineering 12:13-22

R Core Team (2017) R: A Language and Environment for Statistical Computing. Version 3.3.3. R Foundation for Statistical Computing, Vienna, Austria. URL https://www.R-project.org/

Reiswig HM (1971) In situ pumping activities of tropical Demospongiae. Mar Biol 9:38-50

Rochman CM (2018) Microplastics research—from sink to source. Science 360:28-29

Roscher S, Hoffmann R, Ambacher O (2019) Determination of the graphene-graphite ratio of graphene powder by Raman 2D band symmetry analysis. Anal Methods 11:1224-1228

Schindelin J, Arganda-Carreras I, Frise E, et al (2012) Fiji: an open-source platform for biological- 
bioRxiv preprint doi: https://doi org/10.1101/2020.05 26.116012; this version posted May 28,2020 . The copyright holder for this preprint (which was not certified by peer review) is the author/funder, who has granted bioRxiv a license to display the preprint in perpetuity. It is made available under aCC-BY-NC-ND 4.0 International license.

image analysis. Nat Methods 9:676-682

Schrimpf W, Barth A, Hendrix J, Lamb DC (2018) PAM: A Framework for Integrated Analysis of Imaging, Single-Molecule, and Ensemble Fluorescence Data. Biophys J 114:1518-1528

Selvin J, Shanmugha Priya S, Seghal Kiran G, et al (2009) Sponge-associated marine bacteria as indicators of heavy metal pollution. Microbiol Res 164:352-363

Serpone N, Dondi D, Albini A (2007) Inorganic and organic UV filters: Their role and efficacy in sunscreens and suncare products. Inorganica Chim Acta 360:794-802

Taylor KG, Macquaker JHS (2011) Iron Minerals in Marine Sediments Record Chemical Environments. Elements 7:113-118

Taylor MW, Radax R, Steger D, Wagner M (2007) Sponge-associated microorganisms: evolution, ecology, and biotechnological potential. Microbiol Mol Biol Rev 71:295-347 transport during skeletal growth. J Morphol 190:335-347

Teragawa CK (1985) Mechanical function and regulation of the skeletal network in Dysidea. Duke University, pp 252-258

Teragawa CK (1986b) Particle transport and incorporation during skeleton formation in a keratose sponge: Dysidea etheria. Biol Bull 170:321-334

Thompson CM, North EW, Kennedy VS, White SN (2015) Classifying bivalve larvae using shell pigments using micro-Raman spectroscopy. J Raman Spectrosc 45:349-358 
bioRxiv preprint doi: https://doi.org/10.1101/2020.05 26.116012. this version posted May 28,2020 The copyright holder for this preprint (which was not certified by peer review) is the author/funder, who has granted bioRxiv a license to display the preprint in perpetuity. It is made available under aCC-BY-NC-ND 4.0 International license.

844

845

846

847

848

849

850

851

852

853

854

855

856

857

858

859

860

861

862

863

van Soest RWM (1990) Shallow-water reef sponges of Eastern Indonesia. In: Rützler K (ed) New perspectives in sponge biology. Smithsonian Institute Press, London, pp 302-308

van Soest RWM (1989) The Indonesian sponge fauna: A status report. Neth J Sea Res 23:223-230

Venkateswara Rao J, Srikanth K, Pallela R, Gnaneshwar Rao T (2009) The use of marine sponge, Haliclona tenuiramosa as bioindicator to monitor heavy metal pollution in the coasts of Gulf of Mannar, India. Environ Monit Assess 156:451-459

Voigt O, Wörheide G (2016) A short LSU rRNA fragment as a standard marker for integrative taxonomy in calcareous sponges (Porifera: Calcarea). Org Divers Evol 16:53-64

Willenz PH, van de Vyver G (1982) Endocytosis of latex beads by the exopinacoderm in the fresh water sponge Ephydatia fluviatilis: An in vitro and in situ study in SEM and TEM. Journal of Ultrastructure Research 79:294-306

Wörheide G, Erpenbeck D (2007) DNA taxonomy of sponges—progress and perspectives. J Mar Biol Assoc U K 87:1629-1633

Yahel G, Eerkes-Medrano DI, Leys SP (2006) Size independent selective filtration of ultraplankton by hexactinellid glass sponges. Aquat Microb Ecol 45:181-194

Yamano H, Miyajima T, Koike I (2000) Importance of foraminifera for the formation and maintenance of a coral sand cay: Green Island, Australia. Coral Reefs 19:51-58

Yue J, Dew LR, Bissett DL (1997) Sunscreen composition. US Patent

Zięba-Palus J, Michalska A (2014) Characterization of blue pigments used in automotive paints by Raman spectroscopy. J Forensic Sci 59:943-949 